Instructions for authors, subscriptions and further details:

http://rimcis.hipatiapress.com

\title{
The Effects of COVID 19 Process on Health Care Workers: Analysing of the Relationships between Optimism, Job Stress and Emotional Exhaustion
}

Şefik Özdemir ${ }^{1}$, Gökhan Kerse ${ }^{2}$

1) Aksaray University, Turkey

2) Karamanoglu Mehmetbey University, Turkey

Date of publication: article first published online June, 30 2020; Issue published July, 302020.

Edition period: July 2020 - November 2020

To cite this article: Özdemir, S., \& Kerse, G. (2020). The Effects of COVID 19 Process on Health Care Workers: Analysing of the Relationships between Optimism, Job Stress and Emotional Exhaustion. International and Multidisciplinary Journal of Social Sciences, 9(2), 178-201. doi:

10.17583/rimcis.2020.5849

To link this article: http://doi.org/10.17583/rimcis.2020.5849

\section{PLEASE SCROLL DOWN FOR ARTICLE}

The terms and conditions of use are related to the Open Journal System and to Creative Commons Attribution License(CC-BY). 
Sciences Vol. 9 No. 2 July 2020 pp 178-201

\section{The Effects of COVID-19 Process on Health Care Workers: Analysing of the Relationships between Optimism, Job Stress and Emotional Exhaustion}

Şefik Özdemir

Aksaray University
Gökhan Kerse

Karamanoglu Mehmetbey

University

\section{Abstract}

This research has focused on determining the levels of optimism, stress and emotional exhaustion of health care workers related to COVID-19 and the effect of optimism directly and indirectly (through job stress) on emotional exhaustion caused by Covid19. The data were collected through an online questionnaire with optimism, job stress and emotional exhaustion scales arranged according to COVID-19. The data collected from 169 health care workers working in a city in Turkey were analysed using different statistical programs. The findings obtained has shown that the employees are quite optimistic in this process, and they have also experienced stress and emotional exhaustion even though their levels are lower than optimism. Also, it has been determined that being optimistic despite COVID-19 affects emotional exhaustion caused by COVID-19 both directly and indirectly through work stress. Therefore, the level of optimism in this process has reduced the emotional exhaustion caused by COVID-19; however, this decrease was felt stronger through stress. These findings have contributed to both healthcare managers and relevant official institutions, and to researches related to COVID-19.

Keywords: COVID-19, health care workers, optimism, job stress, emotional exhaustion 


\section{Los Efectos Del Proceso De La}

\section{COVID-19 En Profesionales De La}

\section{Salud: Análisis De Las Relaciones}

\section{Entre Optimismo, Estrés Laboral Y Niveles De Agotamiento Emocional}

Şefik Özdemir

Aksaray University
Gökhan Kerse

Karamanoglu Mehmetbey

University

\section{Resumen}

Esta investigación se ha centrado en determinar los niveles de optimismo, estrés y agotamiento emocional de profesionales de la salud relacionados con COVID-19 y el efecto directo e indirecto del optimismo en el agotamiento emocional causado por Covid-19(a través del estrés laboral). Los datos fueron recolectados a través de un cuestionario en línea con escalas de optimismo, estrés laboral y agotamiento emocional organizadas de acuerdo con COVID-19. Los datos recopilados de 169 profesionales de la salud que trabajan en una ciudad de Turquía se analizaron utilizando diferentes programas estadísticos. Los resultados obtenidos han demostrado que los empleados son bastante optimistas en este proceso, y también han experimentado estrés y agotamiento emocional a pesar de que sus niveles son más bajos que el optimismo. Además, se ha determinado que ser optimista a pesar de COVID-19 afecta el agotamiento emocional causado por COVID-19, tanto directa como indirectamente a través del estrés laboral. Por lo tanto, el nivel de optimismo en este proceso ha reducido el agotamiento emocional causado por COVID-19. Sin embargo, esta disminución se sintió más fuerte a través del estrés. Estos hallazgos han contribuido tanto a los gerentes de atención médica como a las instituciones oficiales relevantes, y a las investigaciones relacionadas con COVID-19.

Palabras clave: COVID-19, profesionales de la salud, optimismo, estrés laboral, agotamiento emocional. 
W hile COVID-19, which was stated to have emerged in Wuhan, China in December 2019, was initially considered as an epidemic that has the potential to affect only China and the surrounding countries but it has become a global pandemic in a short time (Aslan, 2020; Bag, \& Sade, 2020; Zheng et al., 2020). In fact, as of 15.06.2020, COVID19 was transmitted to 7.690 .708 people in the world, and 427.630 of them died. Because of COVID-19, as of this date, 117.566 people in the USA, 43.485 people in Brazil, 34.371 people in Italy, 29.673 people in the UK, 29.407 people in France, and 27.136 people in Spain lost their lives, while the number of death was 4.825 in Turkey (Google Haberler, n.d.).

Compared with the mentioned countries, the small number of deaths and receiving relatively more success in combating the pandemic in Turkey is attributable to several reasons. Among these reasons, the following can be listed primarily; (a) having a higher capacity of intensive care beds than the average of OECD countries and many countries, (b) announcement of the majority of public and private hospitals as "pandemic hospital" in the first two months of the pandemic, (c) decreased applications of patients other than COVID-19 to hospitals, (d) having a relatively low ratio of people over the age of 60 to the population, compared to European countries, (e) not to have severe hospital bed and intensive care bed shortage during the pandemic, (f) supplementing 32.000 new health personnel (TTB, 2020), (g) sharing pandemic data transparently every day and, (i) informing the public about the importance of social distance, mask and hygiene.

As stated above, despite all the precautions taken, COVID-19 pandemic threatened human life and caused the death of many people all over the world. Furthermore, COVID-19 begun to negatively affect almost all economic and social parameters in a short time, and it has still continued to affect. All these sudden and rapid developments have prompted scientists from different disciplines to investigate the effects of COVID-19. In this process, researchers have suggested that the COVID-19 pandemic affects many areas such as politics, tourism, aviation, transportation, sports and education (van Holm, Monaghan, Shahar, Messina \& Surprenant, 2020; Blais, Bol, Giani \& Loewen, 2020; Gautam, \& Sharma, 2020; Gössling, Scott \& Hall, 2020; Acar, 2020; Atkeson, 2020; Akca, 2020; Burgess \& Sievertsen, 2020; Turkmen \& Ozsari, 2020; Joob \& Wiwanitkit, 2020), and produces 
psychological and behavioural outcomes in communities (Li, Yanget al., 2020; Kwoket al., 2020; Wang et al., 2020; Pourhaji, Ghanbarizadeh, Zarmehri, Bazrafshan \& Gholian-Aval, 2020; Bostan, Erdem, Öztürk, K1lı̨ \& Y1lmaz, 2020; Qiu et al., 2020; Cao et al., 2020).

In this process, one of the issues that few researchers have examined has been the negative mental and psychological effects of COVID-19 on health care workers (Chew et al., 2020; Rana, Mukhtar \& Mukhtar, 2020; Lai et al., 2020; Cai et al., 2020; Bostan, Akbolat, Kaya, Ozata \& Gunes, 2020). COVID-19 has presented unique stress factors and risks for the physical, mental, spiritual and emotional well-being of health care workers (Dewey, Hingle, Goelz \& Linzer, 2020). Also, this pandemic has caused health care workers to change their standard professional life path and to tackle various challenges. The rapid spread of the pandemic and the rapid escalation of the number of cases worldwide has increased the degree of these difficulties.

Ultimately, it has led health care workers to work harder than ever, to get tired, to stay more sleepless, to spend less time with their families, and even to live separate from them. In addition, due to the high risk of infection of these employees who are in direct contact with COVID-19 patients (Moazzami, Razavi-Khorasani, Dooghaie Moghadam, Farokhi \& Rezaei, 2020) and even the increasing number of healthcare workers who have the disease, it was thought that the COVID-19 pandemic could have a negative impact on the healthcare workers' job stress and emotional exhaustion levels. Despite COVID-19, it has been tried to be determined whether the optimism levels of these employees affect the stress and emotional exhaustion levels at work. Accordingly, the concept of optimism has been discussed first, and then job stress and emotional exhaustion concepts have been defined, and research hypotheses have been developed.

Optimism can be defined as the tendency of individuals to have an expectation that good things will happen to them (Carver, Scheier \& Segerstrom, 2010; Bitmis, 2014; Caliskan \& Uzunkol, 2018). Even if optimists encounter difficulties and challenges about the goals they want to achieve, they act confidently and do not give up until they achieve their goals. These approaches of optimists to have good expectations for the future have positive effects on their lives such as protecting psychological health, stress and reducing anxiety (Carver et al., 1993; Cutrona, Russell, Hessling, Brown 
\& Murry, 2000; Chang \& Sanna, 2001; Gillham \& Reivich, 2004; Abraham, 2007; Bitmis, 2014; Caliskan \& Uzunkol, 2018). Considering these effects, it is thought that optimism will produce a positive result in business life. Accordingly, it is predicted that the levels of job stress and emotional exhaustion will decrease with the high level of optimism of the health care workers.

Stress was previously defined as pressure from the environment, while in later periods it was expressed as a state of tension within the individual. Today's definition includes a perspective that occurs with the interaction of both definitions. Stress, from this point of view, is the psychological and physical condition that arises due to the inadequate resources of the individual to cope with the pressures from the environment (Michie, 2002). This psychological and physical condition can also be seen in business life and is defined as job stress.

Job stress is the tension occurring due to events, conflicts, disagreements or any changes that we witness in the normal flow of our business life (Guclu, 2001; Turunc \& Celik, 2010). This tension situation at work brings along many negative individual and organizational outputs. Job stress increases symptoms of anxiety and depression (Gramstad, Gjestad \& Haver, 2013), leads more alcohol and cigarette consumption (Azagba \& Sharaf, 2011). Job stress is associated with common mental disorders (LaMontagne, Keegel, Louie \& Ostry, 2010), and stress at work affects patient safety incidents (Park \& Kim, 2013). Also, job stress reduces job satisfaction (Rizwan, Waseem \& Bukhari, 2014) and performance (Leung, Chan \& Dongyu, 2011), and increases the turnover intention (Lee, Lee \& Bernstein, 2013).

Burnout is a physical, emotional and mental feeling that occurs as a result of chronic factors such as pressure and stress at work, and wear and fatigue over time (Kerse, 2017). Emotional exhaustion, which is a dimension of burnout, is the feeling that the emotional resources are exhausted in work done and the psychological inability to work (Maslach, Jackson \& Leiter, 1997). In other words, emotional exhaustion is the individual's feeling of the lack of energy and emotional exhaustion (Cordes \& Dougherty, 1993). This share of the individual leads to the emergence of many negative situations: Common mental disorders occur with emotional exhaustion (Tuithof et al., 2017). 
The job satisfaction and organizational commitment of an emotionally exhausted employee decreases (Dishop, Green, Torres \& Aarons, 2019). With emotional exhaustion, anti-productivity behaviours increase (Chen et al., 2020), the level of performance at work decreases (Wright \& Cropanzano, 1998), and productivity losses occur (Ferreira, da Costa Ferreira, Cooper \& Oliveira, 2019). Therefore, determining the factors that will reduce both job stress and emotional exhaustion is essential.

In the COVID-19 process, the employees' optimism related to the future - such as this pandemic will be overcome, and everything will return to normal- can reduce their tension (job stress) and emotional sense of exhaustion (emotional exhaustion) caused by COVID-19. No studies are determining that optimism reduces job stress and emotional exhaustion during the COVID-19 process. However, it has been suggested that optimism reduces stress and emotional exhaustion in studies conducted before COVID19. For example, Chang and Chan (2015) found that optimism reduced burnout in a study on nurses. Alarcon, Bowling and Khazon (2013) determined in their meta-analysis study that there was a negative relationship between optimism and stress.

Cetin, Sesen and Basim (2013) found that optimism was negatively related to emotional exhaustion. Vizoso, Arias-Gundín and Rodríguez (2019), on the other hand, found that there is a negative relationship between optimism and exhaustion. In line with this finding, Ocak and Guler (2017), and Tokmak (2018) determined that there is a negative relationship between optimism and emotional exhaustion.

Xiao et al. (2020) also suggest that providing social and emotional support to healthcare workers during the COVID-19 process reduces anxiety and stress levels and increases their self-efficacy. Accordingly, the following hypotheses were developed in the research:

H1. Optimism levels of health care workers negatively affect the levels of job stress caused by COVID-19.

H2. Optimism levels of health care workers negatively affect the levels of emotional exhaustion caused by COVID-19. 
The COVID-19 process can increase job stress, as it reveals many physical, mental and emotional difficulties, as well as increasing the workload of health care workers. Therefore, in this process, the efforts and energy of the employees to eliminate job stress while performing their duties may lead to emotional exhaustion (Sultana et al., 2020).

Indeed, in the research conducted by Kaya (2010) in the health sector before the COVID-19 process, it was observed that the stress caused by the business environment positively affected emotional exhaustion. Salami (2011) determined in her study that job stress positively affected emotional exhaustion.

Zhang et al. (2020) found that health care workers, who have one-on-one contact with patients during the COVID-19 pandemic, have higher psychological problem symptoms (severe insomnia, anxiety, depression, somatisation and obsessive-compulsive symptoms) than those who do not have one-to-one contact with patients. In another study, Li, Gi et al. (2020) found that nurses directly dealing with the treatment of COVID-19 patients showed symptoms such as anorexia, fatigue, physical fall, sleep disturbance, irritability, inattention, numbness, fear and hopelessness. In line with these explanations and findings, the following hypothesis was developed:

H3. The job stress levels of healthcare workers caused by COVID19 positively affect emotional exhaustion levels.

As seen in the explanations above, the optimism of health care workers despite COVID-19 process may decrease their levels of job stress and emotional exhaustion caused by this process. On the other hand, the decrease in the level of job stress caused by COVID-19 in health care workers can eliminate their emotional exhaustion. This means that job stress can play a mediating role in the effect of being optimistic on emotional exhaustion caused by COVID-19. Accordingly, the following hypothesis can be developed:

H4. Job stress plays an intermediary role in the effect of optimism levels of health care workers on emotional exhaustion levels caused by COVID-19; that is, the job stress levels of the employees, who are 
optimistic despite COVID-19, decrease and the decreasing job stress levels also decrease the emotional exhaustion levels.

\section{Method}

\section{Aims and Participants in the Research}

This research aimed to determine the level of optimism, stress and emotional exhaustion of healthcare professionals related to COVID-19. In addition, the effect of optimism about COVID-19 on emotional exhaustion and the mediating role of job stress in this effect was also tried to be determined. In this regard, the data were collected from health care workers working in a city of Turkey by using a survey technique. Snowball sampling method was used for the data and the created questionnaire was sent to the employees online (via WhatsApp and e-mail).

Those with data loss were eliminated from 183 questionnaires, and analyses were made with the data of 169 participants. $58.6 \%$ of the participants are women, and $66.3 \%$ are married. In terms of age, employees between the ages of 26-35 are the most (46.7\%), and those under the age of 25 are the least $(25.4 \%)$.

Regarding the professions of the participants, $39.1 \%$ of them are emergency medicine/laboratory/x-ray technicians, $26 \%$ are paramedic, $15.4 \%$ are nurses, $10.1 \%$ are health officers, and $9.5 \%$ are health care workers belonging to other professions. When the education levels of the participants were analysed, it was determined that the majority have an associate degree $(35.5 \%)$, and in terms of experience, the majority had over five years of experience $(78.7 \%)$.

\section{Data Collection Tools}

In the research, the items included in the Optimism-Pessimism Scale developed by Caliskan and Uzunkol (2018) were taken as reference for optimism related to COVID-19, and 5 items from this scale were arranged according to the purpose of the study according to COVID-19. The 8-item Job Stress scale developed by Sosik and Goldshalk (2000) was taken as a 
reference to determine the stress level caused by COVID-19, and these items were arranged according to both culture and COVID-19.

Finally, the 9-item scale developed by Maslach, Jackson and Leiter (1981) was taken as reference in determining the level of emotional exhaustion caused by COVID-19. The items in the scale were arranged according to COVID-19. In the research, all items in the scales were prepared as Likert type (1-Strongly Disagree and 5-Strongly Agree) and asked to be answered in the Turkish language. Scale items are given in APPENDIX 1.

\section{Results and Discussion}

\section{Reliability and Validity of the Results}

The data obtained were analysed by using SPSS 25, Amos 18 and Process Macro programs. First, the normal distribution of the data was examined and since the skewness-kurtosis values (Optimism $=-.370$ and -.028 ; Stress = .338 and -.704; Emotional Exhaution $=.047$ and -.718) were between $-2 /+2$ values, it was seen that the data obtained were normally distributed (George ve Mallery, 2016: 114-115), and thus the analyses to be carried out in the next steps should be made accordingly.

Table 1.

Goodness of Fit Values of Scales

\begin{tabular}{lllllll}
\hline \multirow{2}{*}{ Models } & CMIN/DF & RMR & CFI & IFI & TLI & RMSEA \\
\cline { 2 - 6 } & $0<\chi 2 / \mathrm{df} \leq 5$ & $\leq .10$ & $\geq .90$ & $\geq .905$ & $\geq .90$ & $<.05-\leq .08$ \\
\hline Measurement Model(3 factor) & 2.021 & .069 & .930 & .931 & .918 & .078 \\
Model 1 (2 factor) & 3.527 & .107 & .825 & .827 & .796 & .123 \\
Model 2 (2 factor) & 3.406 & .106 & .834 & .835 & .806 & .120 \\
Model 3 (2 factor) & 2.082 & .072 & .925 & .926 & .913 & .080 \\
Model 4 (1 factor) & 3.537 & .107 & .823 & .825 & .795 & .123 \\
\hline Modryyyyyy
\end{tabular}

Measurement model $=$ Optimism, Job Stress and Emotional Exhaustion were handled in separate factors.

Model 1= Optimism and Job Stress are combined in a single factor.

Model 2= Optimism and Emotional Exhaustion are combined in a single factor.

Model 3= Job Stress and Emotional Exhaustion are combined in a single factor.

Model 4= Optimism, Job Stress and Emotional Exhaustion are combined in a single factor. 
Afterwards, the reliability of the scales used was examined and it was seen that the Cronbach alpha coefficient and CR values of each scale met the reference value of 0.70 (Table 2). Confirmatory factor analysis was performed to determine the validity of the scale items and the primary and alternative models (Model 1, Model 2, Model 3, Model 4) were compared.

The basic model considered by this research was found to be the most meaningful model for the referenced values (Table, 1). In addition, the AVE values of the scales were also calculated and it was observed that these values were higher than 0.50 . Therefore, scale validities were also provided.

\section{Testing the Research Hypothesis}

Correlation analysis findings showing levels of optimism, job stress and emotional exhaustion related to COVID-19 and the relationships between these variables are presented in Table 2 . In the interpretation of the findings related to the averages in the table; the criteria of 1-1.80 as very low, 1.812.60 as low, 2.61-3.40 as medium, 3.41-4.20 as high and 4.21-5.00 as very high were used.

Table 2.

Findings Related to Correlation and Pre-Acceptance

\begin{tabular}{lllllllll}
\hline Variables & $X$ & $S D$ & 1 & 2 & 3 & $A V E$ & CR & $\begin{array}{l}\text { Cronbach } \\
\text { Alpha }\end{array}$ \\
\hline 1-Optimism & 3.494 & .847 & 1 & & & .635 & .897 & .899 \\
2- Job Stress & 3.113 & 1.024 & $-.425^{* *}$ & 1 & & .615 & .927 & .931 \\
3- Emotional & 2.755 & .897 & $-.479^{* *}$ & $.846^{* *}$ & 1 & .517 & .904 & .910 \\
Exhaustion & & & & & & & & \\
\hline
\end{tabular}

When Table 2 is examined, the following results are achieved: health care workers have a high level of optimism about overcoming COVID-19 (mean $=3.494$ ), COVID-19 causes moderate stress on them (mean $=3.113$ ) and although it is relatively low compared to the level of stress, they seem to feel moderately emotional exhausted due to COVID-19 (mean $=2.755)$. Findings of the relationship between the variables show that there are negative relationship between Optimism related to COVID-19 and stress $(r=-.425, p$ 
$<.01)$ and Emotional Exhaustion $(\mathrm{r}=-.479, \mathrm{p}<.01)$; while there is a positive relationship ( $\mathrm{r}=.846, \mathrm{p}<.01)$ between stress and emotional exhaustion.

Research hypotheses were tested by making analysis with Process Macro program with SPSS extension developed by Hayes. Regression analysis (based on bootstrap method) was used in the test of the intermediary hypothesis and the findings are given in Figure 1.

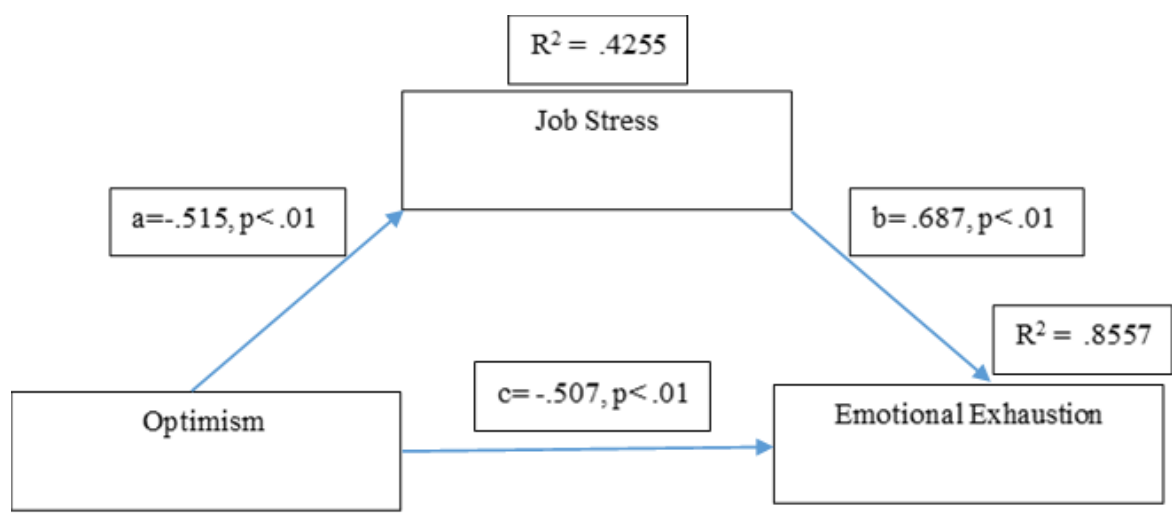

$$
\begin{aligned}
& \text { Direct effect }\left(c^{\prime}\right)=-.154, p<.01 \\
& \text { Indirect effect }=-.353, \% 95 \text { CI }[-.4905,-.2285]
\end{aligned}
$$

Figure 1.Findings of the Hypothesis Test

According to the findings in Figure 1, optimism about COVID-19 negatively affects the stress $(b=-.515, p<.01, \% 95 C I[-.6820,-.3475])$ and emotional exhaustion $(b=-.154, p<.01$, \%95CI [-.2467, -.0610]), caused by COVID-19. In addition, job stress, caused by COVID-19, positively affects the health care workers' emotional exhaustion level $(b=.687, p<.01,95 \% \mathrm{CI}$. $.6097, .7632)$. Therefore, $\mathrm{H} 1, \mathrm{H} 2$ and $\mathrm{H} 3$ are accepted.

In addition to the direct effect of optimism about COVID-19 on emotional exhaustion caused by COVID-19 ( $b=-.154, p<.01, \% 95$ CI [-.2467, -.0610]), it also has an indirect effect ( $b=-.353, \mathrm{p}<.01,95 \%$ CI $[-.4905,-.2285])$ (Figure 1). This means that there is partial mediation. In other words, 
optimism related to COVID-19 affects the emotional exhaustion caused by COVID-19 negatively not only directly but also by decreasing the level of stress caused by COVID-19.

\section{Discussion}

The findings obtained in this research, in which the effect of COVID-19 pandemic on health care workers was evaluated in terms of optimism, stress and emotional exhaustion, provided the following contributions to the literature.

First of all, despite the COVID-19, the optimism levels of the healthcare workers and the stress and emotional exhaustion levels caused by the COVID19 were determined. In determining these levels, the scale averages were examined, and the comments were made based on the average findings. The findings showed that the employees were quite optimistic in this process (mean $=3.494$ ), though their levels were lower than optimism, they were also exposed to stress (mean $=3.113$ ) and experienced emotional exhaustion (mean $=2.755)$. The reason for high optimism may be the fewer number of deaths in Turkey (4.825) due to the COVID-19, compared to the USA (117.566), Brazil (43.485), Italy (34.371), the UK (29.673), France (29.407) and Spain (27.136) (Google Habeler, n.d.).

Furthermore, other precautions such as the rapid provision of tests required for the diagnosis of patients with COVID-19, of medicines to be used in the treatment and of materials and equipment to be used by health care workers in Turkey, personnel training on the subject, increasing the number of healthcare staff with new appointments, filiation (contact tracing) works, sharing pandemic data transparently, quarantine practices and closing public places may also play significant roles in a high level of optimism.

Bostan, Akbolat et al. (2020) found that, in Turkey, authorities and the working conditions of health care workers in the fight against COVID-19 are moderate and therefore this finding clearly shows that the precautions have an important share in the high level of optimism. The low level of stress and emotional exhaustion caused by COVID-19 compared to the level of optimism may be due to the high level of belief (that is, optimism) of the 
health care workers that this pandemic process will be overcome and everything will return to the normal with the mentioned precautions.

According to another finding obtained, being optimistic despite COVID19 affects the emotional exhaustion caused by COVID-19, both directly and indirectly (via stress). In other words, the level of optimism in this process reduces the emotional exhaustion caused by COVID-19; however, this reduction is felt stronger through stress. In other words, being optimistic in the process reduces the stress caused by this pandemic, and this decreasing stress provides the reduction of emotional exhaustion.

COVID-19 pandemic has also greatly affected our economic and social life and habits in Turkey, as well as in the world. Even these effects in economic and social life have revealed psychological effects. These effects were not limited to private life, but also reflected on business life, and led to the mental and psychological impact on employees, especially in the health sector (Chew et al., 2020; Rana et al., 2020; Lai et al., 2020; Cai et al., 2020; Bostan, Akbolat et al., 2020b). In this study, it was also determined that the pandemic caused emotional exhaustion, one of these psychological effects. Emotional exhaustion is essential for both private and business life of employees in the health sector, as in other sectors; it creates many negative results both individually and organizationally. As a matter of fact, psychosomatic complaints (Jourdain, \& Chênevert, 2010) and mental health problems arise with the increase of emotional exhaustion (van Daalen, Willemsen, Sanders \& van Veldhoven, 2009).

In addition, emotional exhaustion reduces the commitment to the profession in the health sector (Jourdain, \& Chênevert, 2010), leads to disengagement (Thanacoody, Newman \& Fuchs, 2014) and low patient satisfaction (Gramstad et al., 2002; Argentero, Dell'Olivo \& Ferretti, 2008). Moreover, it increases the intentions of health care workers to leave the job; in other words, it causes the idea of searching for other jobs (Kim et al., 2019). Therefore, health organisations should identify and implement practices that will reduce employee emotional exhaustion; it is particularly important to take the necessary precautions to minimise the emotional exhaustion, especially during this pandemic, where the emotional exhaustion level is high. Since it is unclear when this pandemic will completely disappear and whether or not 
another epidemic will emerge, we must realise the importance of these staff who continue their diligent and devoted work in the field of health.

In addition to the contributions made to the literature with the research findings, it is useful to mention some limitations in the research. One of these limitations is that the research covers employees in a single city due to the pandemic process we are in. Another constraint is the sampling method used. Snowball sampling method was used in the study, and data were collected from a limited number of (169 employees) health care workers. Having these restrictions makes it difficult to generalise the collected data to the sector. On the other hand, no questionnaire was applied to the doctors. These constraints should be considered in future studies.

\section{References}

Abraham, W. T. (2007). Dispositional optimism and pessimism: stability, change, and adaptative recovery following life event experience. Phd thesis. Iowa State University, Iowa.https://lib.dr.iastate.edu/cgi/viewcontent.cgi?article=16624\&con text=rtd

Acar, Y. (2020). Yeni koronavirüs (covıd-19) salgını ve turizm faaliyetlerine etkisi. Güncel Turizm Araştırmaları Dergisi, 4(1), 7-21.

Akca, M. (2020). COVID-19'un havacılık sektörüne etkisi. Avrasya Sosyal ve Ekonomi Araştırmaları Dergisi, 7(4), 45-64.

Alarcon, G.M., Bowling, N.A., \& Khazon, S. (2013). Great expectations: A meta-analytic examination of optimism and hope. Personality and Individual Differences, 54, 821- 827.

https://doi.org/10.1016/j.paid.2012.12.004

Argentero, P., Dell'Olivo B., \& Ferretti, M.S. (2008). Staff Burnout and Patient Satisfaction With the Quality of Dialysis Care. American Journal of Kidney Diseases, 51(1), 80-92. https://doi.org/10.1053/j.ajkd.2007.09.011

Aslan, R. (2020). Tarihten günümüze epidemiler, pandemiler ve Covid-19. Ayrintı Dergisi, 8(85), 35-41.

Atkeson, A. G. (2020). What will be the economic impact of COVID-19 in the US? Rough estimates of disease scenarios, Staff Report 595, 
192 Özdemir \& Kerse -Effects of COVID-19 on Health Care Workers

Federal Reserve bank of

Minneapolis.http://acdc2007.free.fr/nber26867.pdf

Azagba, S.,\& Sharaf, M. F. (2011). The effect of job stress on smoking and alcohol consumption. Azagba and Sharaf Health Economics Review, 1(15), 1-14. http://doi.org/10.1186/2191-1991-1-15

Bag, M.,\& Sade, G. (2020). Dünyada Covid-19: Illk 4 ayında neler yaşandı? Salginin seyri ne durumda?

https://tr.euronews.com/2020/05/04/dunyada-covid-19-salg-n-n-ilk100-gununde-yasananlar-ilk-nerede-ortaya-c-kt-nas-1-yay-ld

Bitmis, M. G. (2014). Öncülleri ve sonuçları ile psikolojik sermaye: sağllk çalışanları üzerine bir araştırma, yayımlanmamış doktora tezi, Hacettepe Üniversitesi Sosyal Bilimler Enstitüsü, Ankara.

Blais, A., Bol, D., Giani, M., \& Loewen, P. J. (2020). The effect of COVID19 lockdowns on political support: Some good news for democracy? European Journal of Political Research.https://doi.org/10.1111/14756765.12401

Bostan, S., Akbolat, M., Kaya, A., Ozata, M., \& Gunes, D. (2020).

Assessments of anxiety levels and working conditions of health employees working in COVID-19 pandemic hospitals. Electronic Journal General Medicine, 17(5), em246.

https://doi.org/10.29333/ejgm/8228

Bostan, S., Erdem, R., Öztürk, Y.E., Kılıç, T., \&Yılmaz, A. (2020). The effect of COVID-19 pandemic on the Turkish society. Electronic Journal of General Medicine, 17(6), em237.

https://doi.org/10.29333/ejgm/7944

Burgess, S., \& Sievertsen, H.H. (2020). Schools, skills and learning: the impact of COVID-19 on Education. VoxEu.

https://voxeu.org/article/impact-covid-19-education

Cai, H., Tu, B., Ma, J., Chen, L., Fu, L., Jiang, Y., \& Zhuang, Q. (2020). Psychological Impact and Coping Strategies of Frontline Medical Staff in Hunan between January and March 2020 during the Outbreak of Coronavirus Disease 2019 (COVID-19) in Hubei, China. Medical Science Monitor: International Medical Journal of Experimental and Clinical Research, 26, e924171. https://doi.org/10.12659/MSM.924171 
Cao, W., Fang, Z., Hou, G., Han, M., Xu, X., Dong, J., \& Zheng, J. (2020). The psychological impact of the COVID-19 epidemic on college students in China. Psychiatry Research, 287, 112934. https://doi.org/10.1016/j.psychres.2020.112934

Carver, C. S., Pozo, C., Harris, S. D., Noriega, V., Scheier, M. F., Robinson, D. S., Ketcham, A. S., Moffat, F. L., Jr., \& Clark, K. C. (1993). How coping mediates the effect of optimism on distress: A study of women with early stage breast cancer. Journal of Personality and Social Psychology, 65(2), 375-390. https://doi.org/10.1037/00223514.65.2.375

Carver, C. S., Scheier, M. F., \& Segerstrom, S. C. (2010).

Optimism. Clinical Psychology Review, 30(7), 879-889. https://doi.org/10.1016/j.cpr.2010.01.006

Chang, E. C., \&Sanna, L. J. (2001). Optimism, pessimism, and positive and negative affectivity in middle-aged adults: a test of a cognitiveaffective model of psychological adjustment. Psychology and Aging, 16(3), 524-531. https://doi.org/10.1037//0882-7974.16.3.524

Chang, Y., \& Chan, H. J. (2015). Optimism and proactive coping in relation to burnout among nurses. Journal of Nursing Management, 23(3), 401-408. https://doi.org/10.1111/jonm. 12148

Chen, H., Richard, O. C., Boncoeur, O. D.,\& Ford, D. L. (2020). Work engagement, emotional exhaustion, and counterproductive work behavior. Journal of Business Research, 114, 30-41. https://doi.org/10.1016/j.jbusres.2020.03.025

Chew, N., Lee, G., Tan, B., Jing, M., Goh, Y., Ngiam, N., Yeo, L., Ahmad, A., Ahmed Khan, F., Napolean Shanmugam, G., Sharma, A. K., Komalkumar, R. N., Meenakshi, P. V., Shah, K., Patel, B., Chan, B., Sunny, S., Chandra, B., Ong, J., Paliwal, P. R., ... Sharma, V. K. (2020). A multinational, multicentre study on the psychological outcomes and associated physical symptoms amongst healthcare workers during COVID-19 outbreak. Brain, Behavior, and Immunity, S0889-1591(20)30523-7. Advance online publication. https://doi.org/10.1016/j.bbi.2020.04.049 
194 Özdemir \& Kerse -Effects of COVID-19 on Health Care Workers

Cordes, C. L., \& Dougherty, T. W. (1993). A review and an integration of research on job burnout. Academy of Management Review, 18(4), 621656.https://doi.org/10.2307/258593

Cutrona, C. E., Russell, D. W., Hessling, R. M., Brown, P. A., \& Murry, V. (2000). Direct and moderating effects of community context on the psychological well-being of African American women. Journal of Personality and Social Psychology, 79(6), 1088-1101. https://doi.org/10.1037//0022-3514.79.6.1088

Caliskan, H., \&Uzunkol, E. (2018). Ergenlerde iyimserlik-kötümserlik ölçeğinin geliştirilmesi: geçerlilik ve güvenirlik çalışması. The Journal of Happiness \& Well-Being, 6(2), 78-95.

Cetin, F., Sesen, H., \& Basim, H. N. (2013). Örgütsel psikolojik sermayenin tükenmişlik sürecine etkileri: Kamu sektöründe bir araştırma. Anadolu University Journal of Social Sciences, 13(3).

Dewey, C., Hingle, S., Goelz, E., \& Linzer, M. (2020). Supporting Clinicians during the COVID-19 Pandemic. Annals of Internal Medicine, 172(11), 752-753. https://doi.org/10.7326/M20-1033

Dishop, C. R., Green, A. E., Torres, E., \& Aarons, G. A. (2019). Predicting Turnover: The Moderating Effect of Functional Climates on Emotional Exhaustion and Work Attitudes. Community Mental Health Journal, 55(5), 733-741. https://doi.org/10.1007/s10597-019-00407-7

Ferreira, A. I., da Costa Ferreira, P., Cooper, C. L., \& Oliveira, D. (2019).

How daily negative affect and emotional exhaustion correlates with work engagement and presenteeism-constrained productivity. International Journal of Stress Management, 26(3), 261-271. https://doi.org/10.1037/str0000114

Gautam, R., \& Sharma, M. (2020). 2019-nCoV Pandemic: A disruptive and stressful atmosphere for Indian academic fraternity. Brain, Behavior, and Immunity, S0889-1591(20)30506-7. Advance online publication. https://doi.org/10.1016/j.bbi.2020.04.025

George, D., \& Mallery, P. (2016). IBM SPSS statistics 23 step by step: A simple guide and reference. Routledge.

Gillham, J., \& Reivich, K. (2004). Cultivating optimism in childhood and adolescence. Annals of the American Academy of Political and Social Science, 591(1), 146-163. https://doi.org/10.1177/0002716203260095 
International and Multidisciplinary Journal of Social Sciences, 9(2)195

Google Haberler (n.d.). Koronavirüs (COVID-19). Google Haberler. https://news.google.com/covid19/map?hl=tr\&gl=TR\&ceid=TR:tr

Gössling, S., Scott, D., \& Hall, C. M. (2020). Pandemics, tourism and global change: a rapid assessment of COVID-19. Journal of Sustainable Tourism, 1-20.

https://doi.org/10.1080/09669582.2020.1758708

Gramstad, T. O., Gjestad, R., \& Haver, B. (2013). Personality traits predict job stress, depression and anxiety among junior physicians. BMC Medical Education, 13(1), 150.https://doi.org/10.1186/1472-6920-13150

Guclu, N. (2001). Stres Yönetimi, G.Ü. Gazi Eğitim Fakültesi Dergisi, 21(1), 91-109.

Joob, B., \& Wiwanitkit, V. (2020). Traumatization in medical staff helping with COVID-19 control. Brain, behavior, and immunity, 87, 10. Advance online publication. https://doi.org/10.1016/j.bbi.2020.03.020 Jourdain, G., \& Chênevert, D. (2010). Job demands-resources, burnout and intention to leave the nursing profession: A questionnaire survey. International Journal of Nursing Studies, 47(6), 709-722. https://doi.org/10.1016/j.ijnurstu.2009.11.007

Kaya, E. (2010). İs stresi ve tükenmişlik duygusunun işten ayrlma niyeti üzerine etkileri: Sağllk personeli üzerinde bir uygulama. Gebze Yüksek Teknoloji Enstitüsü Sosyal Bilimler Enstitüsü, Yayınlanmamış Yüksek Lisans Tezi, Gebze.

Kerse, G. (2017). Adaptation the Turkish language of the job crafting scale and relationship between job crafting and emotional exhaustion. Journal of Business Research-Türk, 9(4), 283-304.

Kim, Y., Lee, E. \& Lee, H. (2019). Association between workplace bullying and burnout, professional quality of life, and turnover intention among clinical nurses. PLoS ONE,14(12), e0226506. https://doi.org/10.1371/journal.pone.0226506

Kwok, K. O., Li, K. K., Chan, H., Yi, Y. Y., Tang, A., Wei, W. I., \& Wong, S. (2020). Community Responses during Early Phase of COVID-19 Epidemic, Hong Kong. Emerging infectious diseases, 26(7), 15751579. https://doi.org/10.3201/eid2607.200500 
Lai, J., Ma, S., Wang, Y., Cai, Z., Hu, J., Wei, N., Wu, J., Du, H., Chen, T., Li, R., Tan, H., Kang, L., Yao, L., Huang, M., Wang, H., Wang, G., Liu, Z., \& Hu, S. (2020). Factors Associated With Mental Health Outcomes Among Health Care Workers Exposed to Coronavirus Disease 2019. JAMA Network Open, 3(3), e203976. https://doi.org/10.1001/jamanetworkopen.2020.3976

LaMontagne, A. D., Keegel, T. Louie, A. M., \& Ostry, A. (2010). Job stress as a preventable upstream determinant of common mental disorders: A review for practitioners and policy-makers. Journal Advances in Mental Health Promotion, Prevention and Early Intervention, 9(1), 17-35. https://doi.org/10.5172/jamh.9.1.17

Lee, Y., Lee, M., \& Bernstein, K. (2013). Effect of workplace bullying and job stress on turnover intention in hospital nurses. Journal of Korean Academy of Psychiatric and Mental Health Nursing, 22(2), 77-87. https://doi.org/10.12934/jkpmhn.2013.22.2.77

Leung, M. Y., Chan, Y. S. I., \& Dongyu, C. (2011). Structural linear relationships between job stress, burnout, physiological stress, and performance of construction project managers. Engineering, Construction and Architectural Management, 18(3), 312-328. https://doi.org/10.1108/09699981111126205

Li, J. B., Yang, A., Dou, K., Wang, L. X., Zhang, M. C., \& Lin, X. (2020). Chinese public's knowledge, perceived severity, and perceived controllability of the COVID-19 and their associations with emotional and behavioural reactions, social participation, and precautionary behaviour: a national survey. PsyArXiv. https://doi.org/10.31234/osf.io/5tmsh

Li, Z., Ge, J., Yang, M., Feng, J., Qiao, M., Jiang, R., Bi, J., Zhan, G., Xu, X., Wang, L., Zhou, Q., Zhou, C., Pan, Y., Liu, S., Zhang, H., Yang, J., Zhu, B., Hu, Y., Hashimoto, K., Jia, Y., ... Yang, C. (2020). Vicarious traumatization in the general public, members, and nonmembers of medical teams aiding in COVID-19 control. Brain, Behavior, and Immunity, S0889-1591(20)30309-3. Advance online publication. https://doi.org/10.1016/j.bbi.2020.03.007

Maslach, C., \& Jackson, S.E. (1981).The measurement of experienced burnout. Journal of Occupational Behavior, 2, 99-113. 
Maslach, C., Jackson, S.E.,\& Leiter, M.P. (1997). Maslach burnout inventory. Consulting Psychologists Press, Palo Alto, 191-218.

Michie, S. (2002). Causes and management of stress at work. Occupational and Environmental Medicine, 59(1), 67-72.

https://doi.org/10.1136/oem.59.1.67

Moazzami, B., Razavi-Khorasani, N., Dooghaie Moghadam, A., Farokhi, E., \& Rezaei, N. (2020). COVID-19 and telemedicine: Immediate action required for maintaining healthcare providers well-being. Journal of Clinical Virology: The Official Publication of the Pan American Society for Clinical Virology, 126, 104345. https://doi.org/10.1016/j.jcv.2020.104345

Ocak, M.,\& Guler, M. (2017). Psikolojik sermayenin tükenmişlik üzerine etkisi: Görgül bir araştırma. Erciyes Üniversitesi İktisadi ve İdari Bilimler Fakültesi Dergisi, 49, 117-134. https://doi.org/10.18070/erciyesiibd.323907

Park, Y.M.,\& Kim, S. Y. (2013). Impacts of job stress and cognitive failure on patient safety incidents among hospital nurses. Safety and Health at Work, 4(4), 210-215. https://doi.org/10.1016/j.shaw.2013.10.003

Pourhaji, F., Ghanbarizadeh, S. R., Zarmehri, H. A., Bazrafshan, E., \& Gholian-Aval, M. (2020). Community responses during early phase of the COVID-19 epidemic: a cross-sectional study. medRxiv. https://doi.org/10.1101/2020.04.04.20053546

Qiu, J., Shen, B., Zhao, M., Wang, Z., Xie, B., \& Xu, Y. (2020). A nationwide survey of psychological distress among Chinese people in the COVID-19 epidemic: implications and policy recommendations. General Psychiatry, 33(2), e100213. https://doi.org/10.1136/gpsych-2020-100213

Rana, W., Mukhtar, S., \& Mukhtar, S. (2020). Mental health of medical workers in Pakistan during the pandemic COVID-19 outbreak. Asian Journal of Psychiatry, 51, 102080. Advance online publication. https://doi.org/10.1016/j.ajp.2020.102080

Rizwan, M., Waseem, A.,\& Bukhari, S. A. (2014). Antecedents of Job Stress and its impact on Job Performance and Job Satisfaction. International Journal of Learning \& Development, 4(2), 187-203. 
198 Özdemir \& Kerse -Effects of COVID-19 on Health Care Workers

Salami, S. O. (2011). Job stress and burnout among lecturers: Personality and social support as moderators. Asian Social Science, 7(5), 110-121. http://doi.org/10.5539/ass.v7n5p110

Sosik, J. J., \& Godshalk, V. M. (2000). Leadership styles, mentoring functions received, and job-related stress: A conceptual model and preliminary study. Journal of Organizational Behavior, 21(4), 365390. https://doi.org/10.1002/(SICI)1099-

1379(200006)21:4<365::AID-JOB14>3.0.CO;2-H

Sultana, A., Sharma, R., Hossain, M. M., Bhattacharya, S., \& Purohit, N. (2020). Burnout among healthcare providers during COVID-19 pandemic: Challenges and evidence-based interventions. SocArXiv. https://doi.org/10.31235/osf.io/4hxga

Thanacoody, P.R., Newman, A.,\& Fuchs, S. (2014). Affective commitment and turnover intentions among healthcare professionals: the role of emotional exhaustion and disengagement. The International Journal of Human Resource Management, 25(13), 1841-1857. http://dx.doi.org/10.1080/09585192.2013.860389.

TTB (2020). Türk Tabipleri Birliği Covid-19 Danışma ve İzleme Kurulu, Türk Tabipleri Birliği Covid-19 Pandemisi iki aylık değerlendirme raporu. https://www.ttb.org.tr/kutuphane/covid19-rapor.pdf

Tokmak, M. (2018). Pozitif psikolojik sermayenin tükenmişlik üzerine etkileri: Kamu çalışanlarına yönelik bir araştırma. Journal of Management \& Economics, 25(3).

http://doi.org/10.18657/yonveek.419469

Tuithof, M., Ten Have, M., Beekman, A., van Dorsselaer, S., Kleinjan, M., Schaufeli, W., \& de Graaf, R. (2017). The interplay between emotional exhaustion, common mental disorders, functioning and health care use in the working population. Journal of Psychosomatic Research, 100, 8-14. https://doi.org/10.1016/j.jpsychores.2017.06.018 Turunc, Ö., \& Celik, M. (2010). Çalışanların algıladıkları örgütsel destek ve iş stresinin örgütsel özdeşleşme ve iş performansına etkisi. Journal of Management \& Economics, 17(2).

Turkmen, M., \& Ozsari, A. (2020). Covid-19 Salgını ve Spor Sektörüne Etkileri. International Journal of Sport Culture and Science, 8, 55-67. https://doi.org/10.14486/IntJSCS.2020.596 
van Daalen, G. Willemsen, T. M., Sanders, K. \& van Veldhoven, M.J.P.M. (2009). Emotional exhaustion and mental health problems among employees doing "people work": The impact of job demands, job resources and family-to-work conflict. International Archives of Occupational Environment \& Health, 82, 291-303. https://doi.org/10.1007/s00420-008-0334-0

van Holm, E., Monaghan, J., Shahar, D. C., Messina, J. P., \& Surprenant, C. (2020). The impact of political ideology on concern and behavior during COVID-19.SSRN.https://doi.org/10.2139/ssrn.3573224

Vizoso, C., Arias-Gundín, O., \& Rodríguez, C. (2019). Exploring coping and optimism as predictors of academic burnout and performance among university students. Educational Psychology, 39(6), 768783.https://doi.org/10.1080/01443410.2018.1545996

Wang, C., Pan, R., Wan, X., Tan, Y., Xu, L., Ho, C. S., \& Ho, R. C. (2020). Immediate Psychological Responses and Associated Factors during the Initial Stage of the 2019 Coronavirus Disease (COVID-19) Epidemic among the General Population in China. International Journal of Environmental Research and Public Health, 17(5), 1729. https://doi.org/10.3390/ijerph17051729

Wright, T. A., \& Cropanzano, R. (1998). Emotional exhaustion as a predictor of job performance and voluntary turnover. The Journal of Applied Psychology, 83(3), 486-493. https://doi.org/10.1037/00219010.83.3.486

Xiao, H., Zhang, Y., Kong, D., Li, S., \& Yang, N. (2020). The Effects of Social Support on Sleep Quality of Medical Staff Treating Patients with Coronavirus Disease 2019 (COVID-19) in January and February 2020 in China. Medical Science Monitor: International Medical Journal of Experimental and Clinical Research, 26, e923549. https://doi.org/10.12659/MSM.923549

Zhang, W., Wang, K., Yin, L., Zhao, W., Xue, Q., Peng, M., Min, B., Tian, Q., Leng, H., Du, J., Chang, H., Yang, Y., Li, W., Shangguan, F., Yan, T., Dong, H., Han, Y., Wang, Y., Cosci, F. \& Wang, H. (2020). Mental health and psychosocial problems of medical health workers during the COVID-19 epidemic in China. Psychotherapy and Psychosomatics, 89(4), 242-250. https://doi.org/10.1159/000507639 
Zheng, M., Gao, Y., Wang, G., Song, G., Liu, S., Sun, D., ... \& Tian, Z.

(2020). Functional exhaustion of antiviral lymphocytes in COVID-19 patients. Cellular \& Molecular Immunology, 17(5), 533535.https://doi.org/10.1038/s41423-020-0402-2

\section{APPENDIX 1}

\section{Optimism}

1. I hope that many things will be better in the future despite COVID-19.

2. Despite COVID-19, every new day means a new hope for me.

3. Despite COVID-19, I believe I will be happier.

4. Despite COVID-19, everything will be fine in the end, no matter what.

5. Despite COVID-19, I believe that I will achieve all my goals in life.

\section{Job Stress}

1. COVID-19 makes me sad at work.

2. COVID-19 is disappointing in my work.

3. COVID-19 makes me think I'm under pressure in my job.

4. COVID-19 makes me nervous at work.

5. The amount of work I have to do in COVID-19 prevents me from doing my job well.

6. COVID-19 puts me in great stress at work.

7. COVID-19 causes me to get angry and nervous in my work.

8. COVID-19 causes my job to put me under great pressure.

\section{Emotional Exhaustion}

1. I feel I am alienated from my work because of COVID-19.

2. Because of COVID-19, I feel spiritually exhausted on the return from the work.

3. Because of COVID-19, I think I cannot bear my work one more day when I get up in the morning. 
4. Because of COVID-19, I think I was so worn out while dealing with people all day.

5. Because of COVID-19, I feel that I am tired of my work.

6. Because of COVID-19, I feel that my job restricts me.

7. Because of COVID-19, I think I have been working a lot on my job.

8. Because of COVID-19, having a job that requires direct contact with people creates stress on me.

9. Because of COVID-19, I feel that I am at the end of the road in my job and exhausted.

Şefik Özdemir is assistant professor at the Faculty of Health Sicences, Aksaray University, Turkey

Gökhan Kerse is associate professor at the Faculty of Economics and Administrative Sciences, Karamanoglu Mehmetbey University, Turkey

Contact Address: sefikozdemir@aksaray.edu.tr 